\title{
European Integration from below: the Construction of the Ems- Dollart Region, 1964-1978
}

\author{
Marijn MOLEMA
}

For many years, the European Union has pursued policies that are designed to increase cooperation in the border regions that cut across its member states. The origins of this policy can be traced back to the early 1960s. It was not until the launch of the INTERREG programmes in the 1990s, however, that support for the social, cultural and economic development of cross-border regions became firmly rooted. A wide-ranging collection of projects and plans were carried out within the INTERREG programme framework, from infrastructural investment to the improvement of tourist facilities. European subsidies for interregional cooperation also had a positive impact on the foundation of cross-border organizations. By 1990, only 34 cross-border organizations had been founded, a number that had risen to 151 by $2006 .{ }^{1}$ It seems that the role played by this aspect of European politics is increasing and may become even more important in the next cycle of European regional policy. ${ }^{2}$ The phenomenon of cross-border cooperation is made all the more interesting by the fact that historically, it has developed in a unique way. People and organizations operating at the European or national levels were not the only important agents in this process. On the contrary, regional actors were very active in matters of cross-border cooperation from the very beginning. In this way, cross-border cooperation has been a bottom-up process within the broader history of European integration.

Cross-border cooperation can be defined as 'more or less institutionalized collaboration between contiguous subnational authorities across national borders' ${ }^{3}$ To date, academic reflection on the historical dimensions of this phenomenon has been limited. Introductions to the themes, theories and methodologies of European history have paid little attention to the regional dimensions of the integration process. ${ }^{4}$ There are some encouraging indications of a burgeoning research tradition, however, in the form of studies that address the move towards mutual interventions in border regions

1. ARBEITSGEMEINSCHAFT EUROPÄISCHER GRENZREGIONEN (Hrsg.), Zusammenarbeit Europäischer Grenzregionen. Bilanz und Perspektiven, Nomos, Baden-Baden, 2008, pp.46-50.

2. EUROPEAN COMMISSION, Investing in Europe's future. Fifth report on economic, social and territorial cohesion, Publications office of the European Union, Luxembourg, 2010, pp.221-222.

3. M. PERKMANN, Cross-border regions in Europe. Significance and drivers of regional cross-border co-operation, in: European Urban and Regional Studies, 2(2003), pp.153-171, here p.156.

4. R. WAKEMAN (ed.), Themes in modern European history since 1945, Routledge, London/New York, 2003; W. LOTH, Explaining European integration: the contribution from historians, in: Journal of European Integration History, 1(2008), pp.9-26; I.T. BEREND, Europe since 1980, Cambridge University Press, Cambridge, 2010. 
across Europe. ${ }^{5}$ I wish to contribute to this emerging field by concentrating on the institutional history of the so-called 'Euregion', an institutional form of cross-border organization that can be traced back to 1958, as I will later explain. The Finnish geographer Anssi Paasi describes Euregions as entities that are actively shaped by various actors in order to organize social and political life. ${ }^{6}$ According to Paasi, regions are complex constructions that result from social relations and discourses. A 'thick description' of the underlying social processes and discourses is required to understand this complexity, and this article can be read as such a description.

In addressing the institutional history of cross-border cooperation, a number of scholars limit their attention to the role played by local and regional governments in the construction of Euregions. ${ }^{7}$ Quite a few actors from other domains in regional society have also played decisive roles in the institutionalization process, however. Several organizations and associations belonging to civil society, the intermediate sphere between the state and individual citizens, have had a considerable impact on the construction of organizational bodies. In order to investigate the role played by civil society actors, among others, this article will concentrate on the Ems-Dollart Region. This Euregion in the Northern Netherlands and North West Germany was founded in 1977. The fact that its founding fathers consisted of Chambers of Commerce and pro-European movements makes the Ems-Dollart Region a special case, and an appropriate subject for an investigation of the interaction between actors operating in several domains of society, at the regional, national and European levels. I will trace the construction of the Ems-Dollart Region from the first initiatives at the beginning of the 1960s, with the help of policy documents, (annual) reports, magazines, archival investigations and interviews with some of the key actors. The analysis ends with the official founding of the cross-border institution, supported by national policymakers, at the end of the 1970s. In this multi-layered historical process, the research questions focus on the leading agents, their motives and the interaction between them. Were the actors involved driven by idealistic, pragmatic of activist ideas?

5. B. WASSENBERG, Vivre et penser la coopération transfrontalière, vol.1: Les régions frontalières françaises, Franz Steiner Verlag, Stuttgart, 2010; M. RIEDER, Von Wandlungen von Territorialität: Transnationalisierung im Alpenwirtschaftsraum seit der EWG, in: Geschichte und Region/Storia e Regione, 2(2007), pp.147-179; S. BOUWENS, Over de streep. Grensarbeid vanuit Zuid-Limburg naar Duitsland, 1958-2001, Verloren, Hilversum, 2008.

6. A. PAASI, The resurgence of the 'Region' and 'Regional Identity': theoretical perspectives and empirical observations on regional dyamics in Europe, in: Review of International Studies, 35(2009), pp.121-146.

7. H. KNIPPENBERG, The Maas-Rhine Euregion: A Laboratory for European Integration?, in: Geopolitics, 3(2004), pp.608-626; T. PIKNER, Reorganizing cross-border governance capacity: the case of the Helsinki-Tallinn Euregio, in: European Urban and Regional Studies, 3(2008), pp.211-227. 


\section{Cross-border cooperation among politicians and policymakers}

At the beginning of the 1960 s, cross-border cooperation was still in its infancy. The Second World War and its aftermath left resentments on both sides. The Dutch in the Northern Netherlands and the Germans in North West Germany took a relatively long time to overcome their mutual animosities. The Dutch could not forget the humiliation of the German occupation. The people of North West Germany, in turn, were suspicious of the Dutch, because the latter had claimed their land as compensation for war damage. Gradually, however, the two sides' negative opinions were replaced by a more cooperative approach, a process that was encouraged by the actions of some extraordinary pioneers.

Horst Gerlach (1919-1990) was one these pioneers. Gerlach lived in Leer, a small city in the border region of Ostfriesland in North West Germany. After heading the employment service in Ostfriesland, Gerlach went on to become a member of the German federal parliament for the Social Democratic Party. He did not limit his political activities to the Bonn political arena, however, and retained links with his own region. In the first half of the $1960 \mathrm{~s}$, he launched a plan to found a cross-border organization, in which the regional administrations of three Dutch provinces (Groningen, Drenthe and Friesland) and the administrative districts of Aurich, Oldenburg and Osnabrück would cooperate. ${ }^{8}$ Gerlach's ideas did not provoke much enthusiasm among the officials of the Federal State of Lower Saxony, however. At the end of 1964, policymakers rejected Gerlach's proposal during a special meeting of the Federal Ministry of Home Affairs in Hanover. ${ }^{9}$ German policymakers intuitively felt that the Dutch would profit more from the proposed cross-border cooperation, and that the Northern Netherlands would have a head start over North West Germany in regional economic development. Although some participants agreed with Gerlach's basic ideas, the meeting concluded that it was too early for real cooperation. North West Germany should first narrow the development gap between the two regions. Moreover, it was expected that the European Commission would shortly present its plans on regional policy, and the participants agreed that it would be better to wait and see what these entailed. In the meantime, cross-border contact with Dutch regional planning authorities could be extended.

One such extension of contact occurred in the German-Dutch Commission for Spatial Planning's Northern sub-commission. After spatial planning had taken root in the 1950s, Dutch and German spatial planners strived to achieve a European-wide vision of spatial development. Many spatial processes were not limited to national boundaries. Dutch planners had some experience with cross-border cooperation within the sphere of spatial planning, as a Benelux Commission for Spatial Planning had existed since 1952. In the course of the 1960s, Dutch and German planners began to work more closely together, leading in 1967 to the founding of the German-Dutch

\footnotetext{
8. Haupstaatsarchiv Hannover (HStAHAN), Nds.50 (Niedersächische Staatskanzlei) Acc.204/97, No. 57, Gerlach an den Ministerpräsidenten, 09.09.1964.
}

9. Ibid., Niederschrift, 17.12.1964. 
Commission for Spatial Planning. ${ }^{10}$ Each country could delegate nine people to the commission, and the Dutch and German governments, as well as the government of Lower Saxony, sent senior officials. The commission's business was limited to matters of national importance. To give more attention to regional issues, two sub-commissions were created, one for the southern cross-border area and the other for the Northern cross-border area. Delegations from several levels of the regional and national administrations were represented at the annual meetings of the sub-commissions North. ${ }^{11}$

It soon became apparent that spatial planning was dominated by national customs and traditions. During the first meeting, the members of the Northern sub-commission entered into a long discussion about the comparability of the Dutch concept of 'core municipalities' (kerngemeenten) and the German concept of 'central places' (Zentrale Orte). ${ }^{12}$ One of the sub-commission's first conclusions was that it would be essential to harmonize these concepts. After three or four years, however, some members had the frustrating feeling that the Northern sub-commission had made little progress in developing mutual understanding. In 1972, T. Puister, head of the Province of Groningen's provincial planning agency, argued that the time was now ripe for formulating a cross-border development plan, which would help to resolve problems common to the regional economies on both sides of the border. ${ }^{13}$ While the other members agreed, no progress was made with the proposed cross-border plan in the years that followed. ${ }^{14}$ The two countries' traditions of spatial planning appeared intractable. No one took the lead in developing the ambitious cross-border plan, and the Northern sub-commission instead concentrated on practical issues.

At the regional level, pressure was being exerted to strengthen cooperation between the Northern Netherlands and North West Germany. Not everyone went as far as the progressive Gerlach, who wanted a new institution. As will be explained further below, however, the passive stance taken by national and regional administrations in matters of cross-border cooperation was criticized. Officials rejected these criticisms by pointing to the German-Dutch Commission for Spatial Planning and its regional Northern sub-commission. These organizations did indeed function as 'lightning conductors' for regional development, but not for long.

10. NIEDERSÄCHSISCHES INNENMINISTERIUM, Deutsch-Niederländische Raumordnungskommission 1967/1977. Dokumentation, Schriften der Landesplanung Niedersachsen, Hannover, 1978, p.58.

11. The heads of the planning agencies of the Dutch Provinces of Groningen, Drenthe, Overijssel and Gelderland were represented. On the German side, the heads of the planning agencies of the State Districts (Regierungsbezirke) of Aurich, Osnabrück and Münster, were represented, as was an official from the German government and the States of Lower Saxony and North Rhine-Westphalia.

12. Staatsarchiv Osnabrück (StAOS), Regierungsbezirk Osnabrück, Rep.430, Dez.108, Akz.2005/022, No.193, 1. Sitzung, 19.06.1968.

13. Ibid., Notiz, 22.08.1972.

14. Ibid., 6. Sitzung, 11.09.1972. 


\section{Economic initiatives}

Economic organizations were among those to encourage the development of crossborder ambitions. The Chamber of Commerce in Veendam was particularly active in this area. The Veendam Chamber of Commerce had jurisdiction over the Eastern part of the Province of Groningen that bordered North West Germany. In his annual speech of 1968, the Chamber of Commerce's chairman, J.E. Duintjer, criticized the Dutch government on the grounds that its regional economic development policy was too one-sided and only focused on Dutch interests. ${ }^{15}$ According to Duintjer, opportunities for cross-border cooperation and the development of a European perspective on regional development were being overlooked. In order to give a constructive impulse to regional initiatives, the Chamber of Commerce embarked on an explorative research project to investigate possibilities for cross-border cooperation. The Chamber was assisted by an economics student, and his supervisor, Jan Postma, and their report was published at the end of $1968 .{ }^{16}$ The report emphasized the similarities between the two regions' economic problems. Potential fields of cooperation were suggested, such as the construction of ports on the estuary of the River Ems, improvement of road traffic, and the modification of various existing development plans. The report concluded by focusing on European regional policy, laying particular stress on European Commission subsidies that were aimed at setting up cross-border structure plans.

The first European-sponsored structure plan with a cross-border focus had been implemented in 1963. The plan investigated the potential for cooperation between Northern France and the Belgian Province of Luxembourg. ${ }^{17}$ At the time, the plan's explicit promotion of cross-border regional development and its lack of concern with national borders were unique. Economic problems and opportunities affecting the whole cross-border region were shown to be at stake, and the plan's approach opened up new perspectives and opportunities for regional development. European policymakers and politicians embraced this new form of cross-border research, because they were keen to extend European policy domains to the regional level. With the exception of Italy, however, the member states of the European Community considered regional policy to be a national responsibility. ${ }^{18}$ Research projects that created opportunities for cross-border research were seen as a harmless step on the way to achieving European actors' higher ambitions.

The report produced by the Veendam Chamber of Commerce also recommended that an extensive, cross-border research project be undertaken, but officials and politicians from the Province of Groningen were unenthusiastic. They did not support

15. CHAMBER OF COMMERCE, Annual report, Veendam, 1968, p.88.

16. J.D. BOER, J.K.T. POSTMA, Over de mogelijkheden van samenwerking tussen Noord-Nederland en Noordwest-Duitsland, Chamber of Commerce, Veendam, 1968.

17. L.J. BRINKHORST, De gemeenten en de Europese gemeenschappen: een analyse van de verdragen van Parijs en Rome, Vereniging Nederlandse Gemeenten, The Hague, 1965, p.11.

18. A. VARSORI, European regional policy: the foundation of solidarity, in: M. DUMOULIN, M.-T. BITCH (ed.), The European Commission, 1958-72: History and memories, Publications office of the European Union, Luxembourg, 2007, pp.411-425. 
the Chamber's proposals and argued that, as the Chamber had proposed the project, it should take responsibility for implementing it. ${ }^{19}$ The Chamber failed to persuade regional politicians to pursue European subsidies to finance a cross-border research project similar to that undertaken in Northern France and the Belgian Province of Luxembourg. The Chamber's officials subsequently contacted neighbouring Chambers in Groningen, Emden (responsible for the North West German region of Ostfriesland), Osnabrück (responsible for the German border region of Emsland) and Meppel (responsible for the Dutch Province of Drenthe). The Chambers of Commerce in Groningen, Veendam, Meppel, Emden and Osnabrück had been meeting regularly since the 1950s. They tended to discuss typical border problems, such as limited border opening times, the lack of adequate border passages and signposting, and the fact that national train schedules took no account of cross-border traffic.

Duintjer and his Secretary, H.F. van der Laan, failed to persuade their colleagues of the necessity of drawing up a cross-border structure plan..$^{20}$ Their colleagues objected to the cost of the research project. Although the European Commission would subsidize the cross-border development plan, the Chambers of Commerce would also be obliged to pay their share of the costs. Moreover, the whole notion of undertaking a cross-border research project was a new one. This caused the officials to hesitate, and a definitive decision was postponed. After a conference on cross-border cooperation had been held by the Northern Netherlands and North West Germany (a significant event that will be further discussed below), the time appeared to be ripe. In April 1971, the Presidents and Secretaries of the five Chambers of Commerce agreed to the initiative. ${ }^{21}$ Every Chamber contributed 5,000 Dutch guilders to fund a preliminary study, which would be carried out by the University of Groningen. Once the preliminary study was complete, the Chambers would submit an official application for a cross-border development study to be conducted by the national governments involved and the European Commission.

The regional momentum was lost, however, due to a simple, trivial chain of events. One of the researchers who had been responsible for conducting the preliminary study left the University of Groningen. Work on the study stopped, and in July 1972, the Chambers decided to complete the study themselves. After this, the project stagnated. In 1973, the researchers seemed to be encountering problems with delivering and comparing some of the necessary statistical data. There were fundamental differences in systems of data collection in the Northern Netherlands and in North West Germany. The lack of priority given to the cross-border study meant that the research activities lost further momentum, and after 1975, nothing more was heard of the preliminary study.

19. Interview with Jan Postma, formerly an economist at the University of Groningen, 23.04.2010.

20. CHAMBER OF COMMERCE, Annual report, Veendam, 1970, p.70.

21. These and the following facts are based on the annual reports of the Chambers of Commerce in Veendam and Emden (Industrie- und Handelskammer für Ostfriesland und Papenburg) and the magazine of the Chamber of Commerce responsible for the Emsland, Mitteilungen der Industrieund Handelskammer zu Osnabrück. 


\section{The European Movement as a catalyst}

Against this rather passive and hesitant backdrop, one pronounced advocate of crossborder cooperation did play the role of catalyst: the European Movement. The European Movement was an idealistic, pro-European non-governmental organization that had been founded in 1948. It took the form of a federation consisting of National Boards, which functioned as umbrella organizations for several pro-European associations. One of the Dutch sections of the European Movement was based in Groningen. Students mainly took the lead, and Erik Bussink and Henk Sol were particularly active in this respect. ${ }^{22}$

Bussink and Sol organized a conference entitled 'A future without borders'. Over two days in March 1971, politicians, policymakers, academics, representatives of the Chambers of Commerce and others met in the City of Groningen. During the conference, the necessity of cross-border cooperation was once more underlined. Several speakers stressed the shared nature of the regions' economic dilemmas, arguing that working together to solve these would lead to new opportunities. The conference stoked the ambitions of the Veendam Chamber of Commerce, whose President and Secretary had been striving for cross-border cooperation for some years. Just like Duintjer and van der Laan from the Veendam Chamber of Commerce, the young and enthusiastic students were inspired by events within the European Economic Community (EEC).

In May 1965, the European Commission had published a report entitled Première communication de la Commission sur la politique régionale dans la communauté économique européenne (First communication from the Commission on regional policy in the European Economic Community). ${ }^{23}$ The report's aims were moderate: while it provided an overview of regional policies implemented by national governments and some opportunities for further European cooperation, no single concrete measure was proposed. Three years after this Communication, a new DirectorateGeneral for Regional Policy was added to the European administrative system. Hans von der Groeben, a German Commissioner who had been a member of the European Commission since its inception in 1958, was made responsible for European regional policy. In October 1969, Von der Groeben published a second and more influential report, A regional policy for the Community. ${ }^{24}$ This report recommended that a European regional development fund be founded. The development fund would provide the European Commission with an instrument for extending its own version of regional policy. It would take some years before the Council of Ministers would agree

22. The information of this and the next paragraph is derived from the magazine of the Dutch branch of the European Movement, Nieuw Europa, volumes 22, 23 and 24(1969-1971).

23. Communauté économique européenne - Commission, Première communication de la Commission sur la politique régionale dans sa communauté économique européenne, Brussels, 11 May 1965, no. II $/ \mathrm{sec}(65) 1170$ final.

24. Commission of the European Communities, A regional policy for the community, Brussels, 15 October 1969, COM(69) 950. 
to Von der Groeben's proposal for a European regional development fund, however. ${ }^{25}$

Nevertheless, the issue had become important enough to be noticed. Although it is likely that many of the details escaped the attention of actors who were involved in the process of European integration, these actors became very interested in the Communities' initiatives. Along with others, the European Movement in Groningen was a spur to progress in European regional policy, creating enough interest and momentum to organize the conference. Moreover, the students looked to the example of the 'Euregio', a cross-border organization that dated back to $1958 .{ }^{26}$ In the Euregio, local administrations from the German regions of Westmünsterland and Grafschaft Bentheim, and the Dutch regions of Twente and the Achterhoek, cooperated on economic, social and cultural matters.

The students organized the conference in Groningen against the background of these two wider developments, and it turned out to be a great success. The positive, energetic conference atmosphere inspired several of the participants to act. We have already seen how the Chambers of Commerce decided to embark on a preliminary study in April 1971. The students from the European Movement also continued with their activities. A working group was founded in the wake of the conference, chaired by Henk Sol. ${ }^{27}$ Representatives from the Chambers of Commerce in Veendam and Emden were invited to participate. The Director of the Emden Chamber of Commerce, Eckart Krömer, involved his colleagues from the Chamber in Osnabrück. At the local administrative level, the most senior official from the German District of Leer, Peter Elster, became an important member. Elster also belonged to the Europa Union, a German organization under the umbrella of the European Movement. On the Dutch side, the local administrative level was represented by the Streekraad OostGroningen, a collaboration involving seventeen municipalities. In 1972, the working group received subsidies from the European Movement (500 guilders) and the District of Leer (250 guilders).

\section{From working group to the Ems Dollart Region}

The working group was initially known as 'Euregio North', but in November 1974, the decision was taken to change the name to 'Euregio Ems Dollart'. ${ }^{28}$ The first Euregio in the Southern border region of Twente, the Achterhoek, Bentheim and Westmünsterland had protested against the use of the name Euregio North, on the grounds that it would allow the working group to capitalize on its existing reputation.

25. A. VARSORI, op.cit., pp.416-424; I. BACHE, S. GEORGE, Politics in the European Union, Oxford University Press, Oxford, 2006, pp.457-463.

26. Interview with Henk Sol, founder of the Working Party Euregion North, 30.09.2008.

27. Ems-Dollart Region, archive of Alfred Spanjer, Report of meeting, 27.04.1971.

28. Kreisarchiv Emsland (KrAEL), Emsland GmbH, inv. no.1583, Report of meeting, 18.11.1974. 
A good alternative was provided by the more neutral topographical entities of the River Ems and Dollart Bay, and in the course of time, the working group became known as the Ems-Dollart Region.

The question of what to call the working group was not the most difficult problem that had to be tackled. In the first years of its existence, the working group's discussions revolved around one key question: did the young process of cross-border cooperation need its own institution? Would it be necessary to create a new organization, and if so, how should it be structured? Some of the members had declared themselves supporters of institutionalization. The students and Elster, as strong advocates of European integration, were keen to create a new organization. The Chambers of Commerce were less enthusiastic, however. Krömer, the Director of the Emden Chamber of Commerce, was a leading sceptical, if constructive, voice in the working group's discussions ${ }^{29}$ In his opinion, neither the Dutch nor the German border regions needed new plans or organizations. There were already enough initiatives for regional development. Instead of new activities, time and energy should be spent on attuning national and regional policies to one another. The representative of the Veendam Chamber of Commerce, Henk Rubingh, who was responsible for the Chamber's secretariat, was less enterprising than his President, Duintjer, and the Director, Van der Laan. Rubingh did not contradict his colleague Krömer and gave the impression that he too was no supporter of a new institute. ${ }^{30}$ The other members of the working group had more or less neutral opinions.

In a crucial meeting of the German group members in April 1974, Krömer sided carefully with the proponents of a cross-border organization. ${ }^{31}$ His colleague from the Osnabrück Chamber of Commerce, Günther Stücke, did the same. The representatives from German economic organizations gave their support to the founding of the Ems-Dollart Region. Their change of opinion was influenced by Gerlach, who had informed the group's German members about recent developments in Brussels. According to Gerlach, the European Commission was prepared to spend approximately 140,000 Deutschmarks on setting up a cross-border structure plan. Moreover, Gerlach reported on recent progress in the creation of a European Fund for Regional Development. During the Paris European Summit in October 1972, the Council of Ministers had approved the establishment of a development fund. ${ }^{32}$ Gerlach informed the group's members about progress in the technical discussions concerning the preconditions for this new and - for the time - ground-breaking instrument. These events at the European level had the effect of stimulating regional actors in North West Germany.

29. Ibid., Notiz Krömer, 06.01.1972.

30. Ibid., Report of meeting, 18.11.1974.

31. Ibid., Report of meeting, 18.04.1974.

32. Europese Commissie, Door de Commissie van de Europese Gemeenschappen ingediend voorstel voor een verordening van de Raad tot oprichting van een Europees regionaal ontwikkelingsfonds, Brussels, 25.07.1973, COM(73) 1170 def. 
In 1975, probably on 24 February, the Dutch and German working group members decided to found an official cross-border organization. ${ }^{33}$ While it took two years to settle the juridical details, in 1977, the first official general meeting was organized by the board, which was made up of five Dutch and five German representatives from the founding organizations. After 1977, the Ems-Dollart Region attracted increasing numbers of members. Local administrations that had waited to see how the new organization would fare, became convinced of the importance of the cross-border cooperation process. ${ }^{34}$

\section{A national impetus}

As we have seen, progress at the regional level was stimulated by events at the European level. What role was left to actors at the national level? National policymakers from both countries' Ministries of Economic Affairs were also very interested in the cross-border cooperation process. First, their interest was motivated by their conviction that the Ministries should not lose the initiative in matters of regional policy. Second, cross-border cooperation offered an opportunity to do something new in an established policy field. ${ }^{35}$ National policymakers were eager to experiment with new perspectives on regional development. These motives led national officials to return to the old idea of setting up a cross-border structure plan.

For one of the governmental deliberative bodies, the German-Dutch Consultative Body for Regional Policy, cross-border cooperation was a permanent concern. The Consultative Body had been founded in 1966, and was tasked with attuning national regional development policies to one another. ${ }^{36}$ Moreover, meetings between senior officials from the Dutch and German Ministries of Economic Affairs, as well as officials from the German States of Lower Saxony and North Rhine-Westphalia, functioned as preliminary talks on European regional policy issues. The officials debated the most recent developments in European politics, thereby allowing the Germans and the Dutch to explore one another's views on the European Commission's new ideas.

In any case, the officials were well-informed about the ambitions of European politicians and policymakers. In 1975, the delegation from the German Ministry of Economic Affairs proposed a research project for the Northern cross-border area,

33. A search of several archives failed to reveal a record of this meeting, and it is probable that one was never made. Based on a reconstruction of other meetings, it is likely that the crucial decision was made in February 1974.

34. H. HOOGAKKER, Land zonder grenzen. Eems Dollard Regio - een kroniek. Land ohne Grenzen. Ems Dollart Region - eine Chronik, Ems Dollart Region, Nieuweschans, 2005, p.51.

35. M. MOLEMA, Regionale kracht. Economisch beleid in Noord-Nederland en Noordwest-Duitsland, 1945-2000, Koninklijke Van Gorcum, Assen, 2011.

36. Nationaal Archief Den Haag (NA), Ministry of Economic Affairs, no.2.06.099, inv. No.148, Notitie aan minister, 17.02.1966. 
which would result in a Regional Action Programme. ${ }^{37}$ The concept of a Regional Action Programme had been derived from the German national approach to regional policy. From 1968 onwards, regional policy had been systematized in 21 Regional Action Programmes that were dispersed over the whole of the Federal Republic. ${ }^{38}$ This national system was then transferred to the cross-border approach. Dutch officials agreed with the German proposal to focus the plan on the Northern border area. Policymakers from the Dutch Ministry of Economic Affairs had already gained significant experience in the Northern Netherlands, due to the fact that a so-called Integral Structure Plan had been set up for the Northern Netherlands in 1973. The crossborder project would thus benefit from this expertise. ${ }^{39}$

The research project was implemented in 1976 and 1977, with assistance and guidance being offered from two sides. First, the European Commission provided the structure for the report that resulted from the cross-border research project. Shortly after the Regional Development Fund had been established in 1975, European policymakers created a scheme for regional development programmes. ${ }^{40}$ Those regions and member states that profited from the Fund were required to list the existing problems faced by economies in particular regions. In addition, they were required to present an overview of the regional policy measures already being implemented in particular areas. National policymakers in Bonn and The Hague used this framework to set up the proposed development plan. Second, the cross-border research project for the Dutch-German Northern border area profited from expertise in the region. In order to acquire the necessary statistical information, the Ministries of Economic Affairs used their contacts at lower levels of the administrative system. The head of the economics department of the Province of Groningen, for example, was made responsible for collecting statistical data from the Dutch Provinces of Groningen and Drenthe. On the German side, Gerhard Hugenberg played a key role. Hugenberg was the Director of Emsland $\mathrm{GmbH}$, a state-subsidized organization responsible for improving the infrastructure of Emsland, a region in North West Germany that borders the Dutch Provinces of Groningen and Drenthe. ${ }^{41}$

Hugenberg coordinated the data collection and led a survey of regional organizations involved in economic development, which investigated these organizations' existing cross-border cooperation activities. Hugenberg processed the survey results in a draft version of the report. Dutch and German officials in The Hague and Bonn

37. Bundesarchiv Koblenz (BAK), Ministry of Economic Affairs, inv. no.218683, Vermerk 18. Gespräch, 11.11.1975.

38. H. KARL, Entwicklung und Ergebnisse regionaler Wirtschaftspoitik in Deutschland, in: H.H. EBERSTEIN, H. KARL (ed.), Handbuch der regionalen Wirtschaftsförderung, OVS Verlag, Cologne, 2008, section A2.

39. BAK, Ministry of Economic Affairs, inv. no.218683, Eysink Smeets to Albert, 16.03.1976.

40. Schema van de programma's voor regionale ontwikkeling, Publicatieblad van de Europese Gemeenschappen, 24.03.1976, No.C 69/2.

41. C. HAVERKAMP, Die Erschließung des Emslandes im 20. Jahrhundert als Beispiel staatlicher regionaler Wirtschaftsförderung, Emsländische Landschaft, Sögel, 1991. 
wrote the final version of the report, which was presented in $1978 .{ }^{42}$ The report's cover proclaimed a new concept: the Ems-Dollart Region. This concept had been adopted from the regional founders of the recently-established cross-border institution, which covered the Northern Netherlands and North West Germany. National policymakers embraced the new regional initiative, which continued to grow in importance over the subsequent decade. In the 1980s, with the unfolding of a European policy for the development of border areas, the two countries' Ministries of Economic Affairs assisted the Ems-Dollart Region's attempts to profit from cross-border funding instruments.

\section{Conclusion}

In the introduction, we asked whether idealistic, activist or pragmatic motives lay behind the creation of the Ems-Dollart Region. Having explored how, why and by whom this early cross-border regional institution was founded, we must conclude that all three motives simultaneously played a role. These motives were combined in a multi-layered process, in which several actors took the lead. Young idealists - members of the European Movement and students at the University of Groningen - acted as catalysts. By organizing a conference in 1971 and heading a working group for cross-border cooperation in the wake of this successful event, they gave a crucial impulse to the formation of cross-border networks. Several Chambers of Commerce were key actors in these networks. They had not previously aimed to create a crossborder institution, but they decided to support the young students' idea on pragmatic grounds. We can describe the attitude of national policymakers from the Ministries of Economic Affairs as 'activist'. First, these policymakers did not want to lose the initiative in regional policy. Second, the notion of extending national experience with regional economic policy to the field of cross-border cooperation structures proved attractive to them. It gave them an opportunity to do something new and challenging in an old policy domain.

All of these actors - the students, the Chambers of Commerce and the national policymakers - were influenced by the European Commission. The Commission's attempts to found a European Fund for Regional Development, which succeeded in 1975 , stimulated idealists to support the creation of a new policy domain. It was thought that cross-border cooperation would become one of the key institutions of European regional policy and a spur to increasing integration between the member states. In the opinion of the Chambers of Commerce, however, the added value of the cross-border institute lay in the utilization of the European Fund. National policymakers, in turn, were inspired by the idea of creating a European dimension in a

42. MINISTERIE VAN ECONOMISCHE ZAKEN, BUNDESMINISTERIUM FÜR WIRTSCHAFT, NIEDERSÄCHSISCHES MINISTERIUM FÜR WIRTSCHAFT UND VERKEHR, Grensoverschrijdend programma - Grenzüberschreitendes Programm, The Hague/Bonn/Hannover, 1978. 
traditional policy domain. Moreover, their interest was driven by bureaucratic considerations: they did not want to lose the initiative in regional development matters, and were keen that contact between the region and the European Commission should be mediated by national Ministries of Economic Affairs. The Ems-Dollart Region was thus created in a process of dynamic interaction involving regional, national and European actors, which operated within different social domains. Further research into cross-border cooperation should take this multi-level perspective as its starting point, in order to reveal the many detailed interactions and significant forces that have influenced one another. 


\section{Jean Monnet's \\ Right-Hand Man}

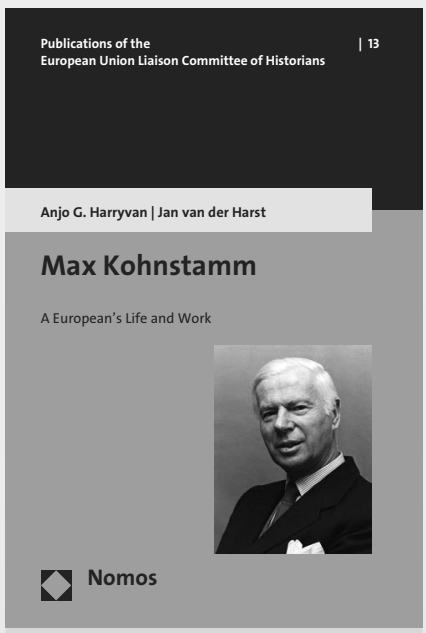

Max Kohnstamm's life tells the story of a revolutionary attempt to abolish war in interstate relations in Europe. As a survivor of the horrors of World War II, he worked with Jean Monnet for nearly three decades, laying the foundations of the present-day European Union. A biography depicting a life of persuasion, perseverance and influence behind the scenes.

\section{Max Kohnstamm}

A European's Life and Work

By Anjo G. Harryvan |

Jan van der Harst

2011, 186 pp., pb., € 34.00, ISBN 978-3-8329-5810-7

(Publications of the European Union Liaison

Committee of Historians, vol. 13) 